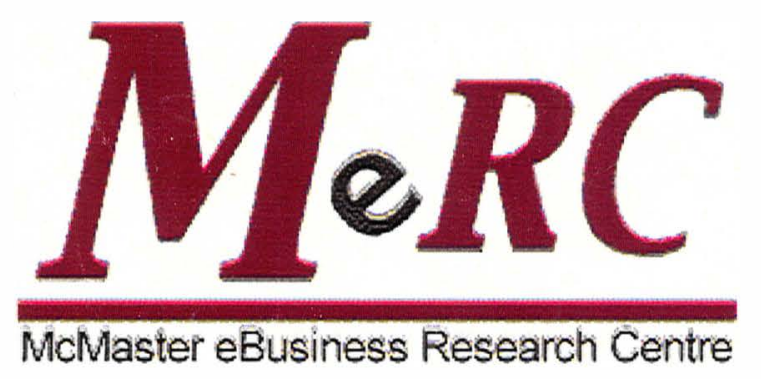

\title{
EFFECT OF NETWORK RELATIONS ON THE ADOPTION OF ELECTRONIC TRADING SYSTEMS
}

By

Ali Reza Montazemi, John J. Siam \& Akbar Esfahanipour

McMaster eBusiness Research Centre (MeRC)

DeGroote School of Business

MeRC Working Paper No. 20

June 2007

Innis

McMaster

University

HF

5548.32

. $\mathrm{M} 385$

no.20 
EFFECT OF NETWORK RELATIONS ON THE ADOPTION OF ELECTRONIC TRADING SYSTEMS

By

Ali Reza Montazemi, John J. Siam, Akbar Esfahanipour

MeRC Working Paper \#20

June 2007

CMcMaster eBusiness Research Centre (MeRC)

DeGroote School of Business

McMaster University

Hamilton, Ontario L8S 4M4

Canada 


\section{TABLE OF CONTENTS}

\section{Page}

Abstract and Keywords................................................... 2

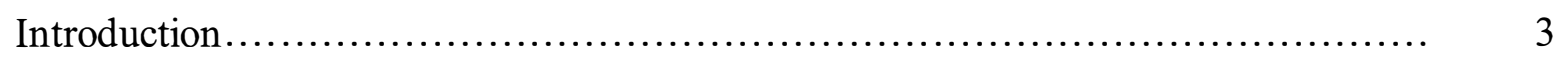

The Fixed-Income Market Environment................................... 5

Conceptual Model of Network Relations........................................ 6

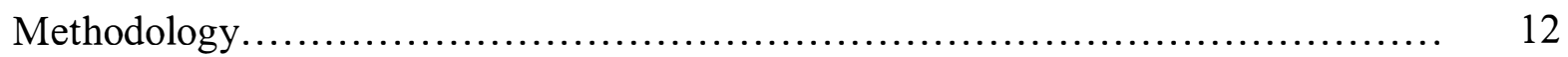

Analysis................................................................ 13

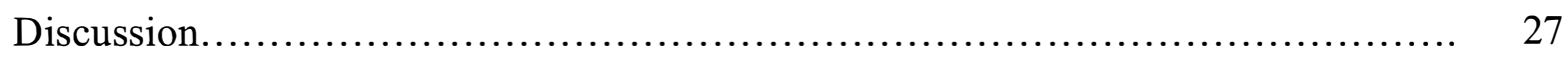

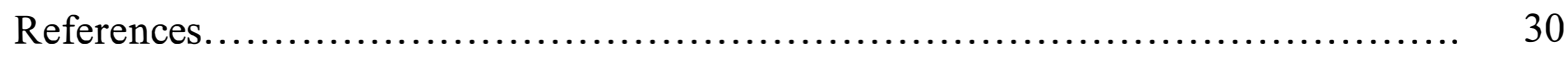

Appendix A: Institutional Client/Dealer Trade Phone Transaction................. 34

Figure 1: $\quad$ Brokerage arrangement and network relations adapted from [39]....... 37

Figure 2: Information flow and network ties among actors in sell-side F1 market.. 38

Figure 3: Information flow and network ties among actors in buy-side F1 market.. 39

Figure 4: $\quad$ Network structure among actors in F1 market....................... 40

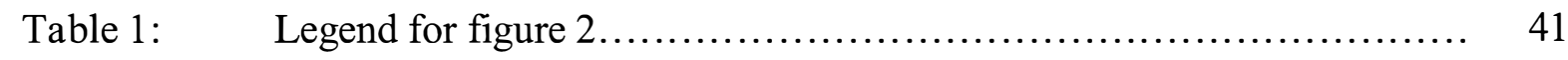

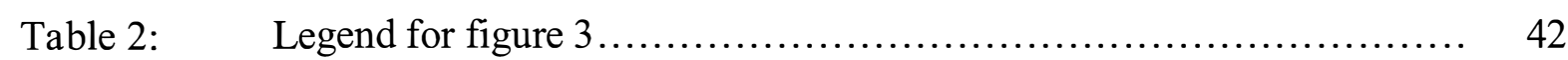




\title{
Effect of Network Relations on the Adoption of Electronic Trading Systems
}

\author{
Ali Reza Montazemi, John J. Siam \& Akbar Esfahanipour \\ DeGroote School of Business, McMaster University
}

\begin{abstract}
Information systems can serve as intermediaries between the buyers and the sellers in a market, creating an "electronic marketplace" that lowers the buyers' cost to acquire information about sellers' prices and product offerings. Although electronic trading systems provide potential to create an efficient market structure, we witness 45 trilliondollar fixed-income (FI) market still makes little use of these systems. Low penetration of electronic trading systems in the marketplace is at odds with the existing IT research doctrine. The reason is that the creation of efficient market structure through electronic marketplace is based on macrolevel interfirm relationships that do not take into account the recurrent microlevel, interpersonal interaction among the market actors. Our empirical investigation, based on face-to-face interviews with 90 fixedincome senior managers and traders from 25 financial institutions, provides a unique insight into the social capital based on social networks of interpersonal relationships in the fixed income market. Our research findings show that the market structure of embedded interpersonal ties enables participants to take advantage of information asymmetry for profit taking. As a result, imposition of electronic trading systems on the present fixed-income market structure is at odds with the present interfirm market norms and business processes enacted for large transactions among market-makers and institutional investors.
\end{abstract}

Keywords: Information flow, Alternative Trading Systems, IT-mediated network ties, embedded relationships, arm's-length relationships, fixed-income market 


\section{Effect of Network Relations on the Adoption of Electronic Trading Systems}

\section{Introduction}

Markets have three main functions: matching buyers and sellers; facilitating an efficient exchange of information, goods, services and payments associated with market transactions; and providing an institutional infrastructure, such as a legal and regulatory framework, that enables the market to function efficiently [4]. Operational efficiency means that market participants are able to conduct transactions at competitive cost, and informational efficiency means that all available information is incorporated into the price. The degree of informational and operational efficiency determines the extent to which markets are allocationally effective. Information systems can serve as intermediaries between the buyers and the sellers in a market, creating an "electronic marketplace" that makes it less expensive for buyers to acquire information about sellers' product offerings and prices $[5,6]$. Thus, one would expect electronic trading systems to replace the inefficiencies of traditional face-to-face and telephone systems among buyers and sellers in the financial market place. Recent research shows, however, that electronic trading systems have had little impact on the traditional methods of brokerage in financial markets [25, 35, 49]. To better understand factors inhibiting the use of electronic trading systems in support of transactions, we believe, as do others ([3,39], for example), that it is necessary to study the microstructure of the markets. In this endeavor, our focus in this paper is on the secondary fixed-income market microstructure among the actors to better understand the inhibiting issues affecting use of electronic trading systems.

In recent years, we have witnessed the growth of the use of electronic trading systems in support of Fixed-Income (FI) trade. To date, there are at least 23 platforms used internationally to enhance the efficiency of electronic trade execution and to reduce user costs [42]. A recent survey [42] shows that virtually all trading platforms offer a combination of the following services: (a) pricing data, (b) confirmation and allocation services, (c) pre-trade analytics, (d) matching services, (e) electronic 
research delivery, (f) regulatory compliance services, $(\mathrm{g})$ risk monitoring or management services and (h) identity management services. In spite of the variety of services offered by the trading platforms, about $90 \%$ of the trade volume is performed by phone or squawk box in the FI market $[16,35,42]$. The reasons reported for this relatively low use of electronic trading systems are generally anecdotal, such as (1) the variety and complexity of different type of bonds (the mortgage-related market has almost 2 million issues, for example) making it difficult to present them on a single platform, (2) the variation in the design of different electronic platforms, which makes it difficult to use a common interface, and (3) the effect of platform ownership by competing interest groups which makes it difficult to adopt a system across the board [16]. The shortcoming of research to this point is that it has focused on the "electronic integration effect" of the FI trading systems, assuming arm's-length relationship between buyers and sellers to be the only desirable outcome. But this overlooks the significance of social capital in the form of "socially embedded network relations" among the actors which enable them to exchange information towards mutually profitable trades. It is probable that the embedded relationships among the actors cannot be easily replaced by a self-serve technology [39] such as electronic trading systems.

Thus, our research objective is to explore the ways information flow mediates brokerage relationships that are enacted through interaction of actors in the FI market and assess its effect on the use of electronic trading systems. To this end, the next section details the FI market environment. Section three presents a framework to analyze information flow among actors in social networks. Section four details the methodology used to collect data from actors in the FI market. Application of our framework in the context of FI market is presented next, and the paper closes with a discussion of the findings and implication for practice and research. 


\section{The Fixed-Income Market Environment}

An FI security is defined as one whose income stream is fixed for the duration of the loan and whose maturity and face value are known. It is estimated that the global FI market is about $\$ 45$ trillion. In a typical FI market there are four major players: securities issuers, dealers, brokers and investors. Fixedincome securities are issued by the borrower-govermments or corporations - and are purchased by a dealer or a group of dealers for resale. Actual trading takes place in the secondary market which lists and trades primary issues once they are sold. Market quotes (benchmark prices) to the FI market are provided through information vendors, such as Reuters and Bloomberg, who are connected electronically to the dealers' market. Investors (buy-side) are usually blind to the "real" and "live" market, and the prices (quotes) provided to them serve as a benchmark and are the first step in a process that may lead to a trade. The "real" or "live" dealers' markets normally take place over the phone and represent a binding commitment by the dealer either to buy or sell [35]. Fixed-income market infrastructure is built around information asymmetry.

Information is critical to market transparency in FI trade [2, 10, 36]. Market transparency refers to the amount of quote, price and volume information available to markets and to the general public. In FI markets, dealers provide quotes to a potential counterparty, and they also act as market-makers, taking on inventory risk. Complete transparency in these circumstances may reduce their ability to manage this risk, which could have the adverse effect of reducing liquidity and increasing transaction costs.

Sell-side firms have traditionally played a critical role in FI markets. In negotiated deals (as opposed to auction-based deals) which are the dominant type of transactions in FI market, sell-side firms utilize their market expertise, which constitutes an information asymmetry that works to their advantage [16]. The information needs for sell-side firms in particular include information that they would like to 
receive about positions held in the buy-side portfolios to make better trading recommendations [36] and to gain control over the significant effects of information asymmetry [27, 33, 4950, 51]. Thus, brokerage relationship among the actors in FI market has a major impact on their daily transactions.

Next, we present a model to explore the ways information flow mediates brokerage relationships that are enacted through interaction of actors in the FI market and assess its effect on the use of electronic trading systems.

\section{Conceptual Model of Network Relations}

Relational view of information seeking and learning of actors in a social network indicate that, faced with information asymmetry, the probability of seeking information from another person is a function of: (1) knowing what that person knows; (2) valuing what that person knows; (3) being able to gain timely access to that person's thinking; and (4) perceiving that seeking information from that person would not be too costly [7]. The benefit accrued through exchange of information among actors in a social network is labeled as social capital. More broadly, social capital can be defined as resources embedded in a social network which accessed and/or mobilized towards specific actions (such as the strategic advantage of the firm) [9]. It consists of three components: (1) resources embedded in a social structure (embeddedness); (2) accessibility to such social resources by individuals (accessibility); and (3) use or mobilization of such social resources by individuals towards specific actions (use).

We adopt the Schultz and Orlikowski's network relation model [39] to explore the ways information flow mediates brokerage relationships that are enacted through interaction of actors in the FI market. This model, depicted in Figure 1, presents two different types of network relations that vary according to structure (i.e. network ties, network configuration, and network structure) and agency (i.e., cognitive and relational dimensions).

Figure 1 about here 


\section{Network ties}

Actors use direct and indirect ties to seek private information under conditions of information asymmetry [40]. Direct tie can be defined as a personal relationship between two actors (e.g., buyer and seller). Indirect tie, however, is a relationship between two actors who are not directly connected but through whom a connection can be made through a social network of each party's direct ties [9]. Direct ties between actors could shift the logic of the transaction from one of economic relationship to one of social relationship [32]. By embedding a transaction in an ongoing social relationship, direct ties motivate both parties to maintain the relationship in a fair and trusting manner, and generate a sense of obligation between the parties, which causes them to behave generously towards each other [21]. Thus, in the absence of direct prior ties, actors are more likely to engage in zero-sum business transactions through arm's-length ties [45]. Furthermore, embedding economic exchange in social attachments can both create unique value and motivate exchange partners to share the value for their mutual benefit [46]. Embeddedness demonstrates how informal mechanisms of trust and agreed-upon expectations of cooperative behavior arise in relationships and facilitate resource transfers between actors. Arm'slength ties, on the other hand, are characterized by lean and sporadic transactions [44]. These ties determine the degree to which an actor can access heterogeneous information in a market, even if that information is publicly available, because actors use network ties to search for up-to-date information [9]. Since arm's-length ties require little investment in time or mutual obligation, they enable actors to economically maintain many ties to other actors. Therefore, when public information is scattered unevenly among actors in a market, arm's-length ties should provide an effective and economical means for acquiring that information [47].

Embedded ties, on the other hand, encourage private knowledge transfer because expectations of trust and reciprocity provide assurances that the transfer will be used to the mutual benefit of both 
parties [44]. Uzzi and Gillespie [46] contend that the process of embedding commercial transactions instills into future exchanges expectations of trust and reciprocity that promote unique value creation in the relationship. These expectations arise because the embeddedness of commercial transactions in social attachments endow the commercial transaction with expectations of exchange that people normally use for transacting with individuals they have come to know well, expectations that offer a reliable template for managing transactions from what they have learned in their prior experiences. Embedded ties, therefore, are well suited for the transfer of novel and private information. Nonetheless, embedded ties and arm's-length ties are complementary rather than cannibalistic when they are combined within the same social network [44]: arm's-length ties are superior at "shopping" the market for publicly available information, and embedded ties are superior at "plugging" actors into the unique private information network. This enables organizations to benefit from social capital through embedded ties in social networks. The reason is that information can be expected to spread across the people in a market, but it will circulate within the social network before reaching those outside the network. Therefore, the network members are better informed and take advantage of their information asymmetry relative to others in the market.

\section{Network configuration}

Network ties provide the channels for information transmission, but the overall configuration of these ties constitutes an important facet of social capital [37]. In line with our research objective, let us place the above network ties within the context of brokerage behavior in social systems. Marsden [31, p. 202] defines brokerage as a process "by which intermediary actors facilitate transactions between other actors lacking access to or trust in one another." Thus, any brokered exchange can be thought of as a relation involving three actors, two of whom are the actual parties to the transaction and one of whom is the intermediary or broker [18]. Gould and Fernandez [18] identified five structurally distinct types of brokerage configurations by examining differences in activities and interests of the actors in the network 
relationships. Two of their five brokering types - gatekeeper and liaison - are particularly relevant to our discussion of IT-mediated network relationships in FI market.

A liaison brokerage arrangement (Figure 1a) consists of actors who have different interests and are without any allegiances among them. In this liaison arrangement, the broker is seen to be both independent and unbiased (i.e., arm's-length tie between the broker and the customer). In contrast, in the gatekeeper brokerage arrangement (Figure 1b), the broker's interests tend to be aligned with those of the buyer. As a gatekeeper, the broker gathers information from a third party and manipulates it by filtering, sorting and editing it before distributing a selective content of it to the buyer (i.e., embedded tie between the broker and the buyer). The conduct and performance of firms can be more fully understood by examining the network of relationships in which they are embedded [21], which is described below.

\section{Network Structure}

There are two complementary schools of thought in regard to network structure: one advocated by Burt [9] and the other by Coleman [11]. Redundant ties and the benefits of trust supporting coordination in long-term relationships characterize the Coleman's network. Burt's networks, on the other hand, focus on structural holes and on optimizing the information flow, while simultaneously minimizing the cost of maintaining relationships. Strong ties have been shown to be superior at exchanging tacit knowledge, and they also serve as part of the social control mechanism which governs partnership behaviors. Weak ties, on the other hand, are more likely than strong ties to serve as "local bridges" to distant others who possess unique information $[19,26]$. Nonetheless, the evidence presented in the literature shows that the effectiveness of a network depends on both strong and weak ties since different forms of ties provide distinct and different resources [24].

Embedded ties between actors (broker and client, for example), to exchange private information within the framework of the gatekeeper brokerage arrangement, are affected by interpersonal relations 
and cognitive attributes: the cognitive dimension consists of shared codes and language as well as shared narratives, whereas the relational dimension consists of trust, norms, obligations and identification,. A brief description of relational and cognitive dimensions, used in this research, is provided next.

\section{Cognitive Dimension}

Intellectual capital is a social artifact and that knowledge and that meaning are always embedded in a social context — both created and sustained through ongoing relationships in such collectivities. This sharing may come about in two main ways: through the existence of shared language and vocabulary or through the sharing of collective narratives [37].

Shared language and codes: Language has a direct and important function in social relations, for it is the means by which people discuss and exchange information, ask questions and conduct business in society as follows.

1. Language influences our perception. Codes organize sensory data into perceptual categories and provide a frame of reference for observing and interpreting our environment. Thus, language filters out those events for which terms do not exist in the language and allows in those activities for which terms do exist;

2. A shared language enhances combination capability. The existence of a shared vocabulary enables the combining of information.

Shared narratives: share narratives consist of myths, stories and metaphors that provide powerful means in communities for creating, exchanging and preserving rich sets of meanings. There are two modes to this: (a) the information or pragmatic mode that suggests a process of knowledge creation rooted in rational analysis and good argument, and (b) the narrative mode. This is represented in synthetic narratives, such as fairy tales, myths and legends, good stories and metaphors.

\section{Relational Dimension}


Trust: Drawing on social psychology and marketing, Doney and Cannon [13] define trust as the perceived credibility and benevolence of a target of trust. The first dimension of trust focuses on the objective credibility of an exchange partner, an expectancy that the partner's word or written statement can be relied on. The second dimension of trust, benevolence, is the extent to which one partner is genuinely interested in the other partner's welfare and is motivated to seek joint gain. To this end, Nahapiet and Ghoshal [37] have identified the following four attributes of trust that need to be assessed:

1. Belief in the good intent and concern of exchange partners.

2. Belief in their competence and capability

3. Belief in their reliability

4. Belief in their perceived openness

Norms: A norm exists when the socially defined right to control an action is held not by the actor but by others. Thus, it represents a degree of consensus in the social system. Nahapiet and Ghoshal [37] identify the following six attributes to assess norms affecting social capital:

1. Cooperation

2. Open disclosure of information

3. Building loyalty

4. Willingness to value and respond to diversity

5. Openness to criticism

6. Tolerance of failure

Obligations and expectations: Obligations represent a commitment or duty to undertake some activity in the future.

Identification: Identification is the process whereby individuals see themselves as one with another actor or group of actors. This may result from their membership in that group or through the group's operation as a reference group, "in which the individual takes the values or standards of other individuals or groups as a comparative frame of reference."

In the following section, we describe the methodology used in the collection of data to assess relational ties and information flow among actors in the FI market within the context of the above framework. 


\section{Methodology}

Our research objective is to explore the ways information flow mediates brokerage relationships that are enacted through interaction of actors in the FI market and assess its effect on the use of electronic trading systems. To this end, the data were collected through face-to-face interviews using a semistructured questionnaire. We used the Investment Dealers Association members' list to select financial institutions for data collection. Next we called senior management in each institution to explain the objective of the study and ask for their participation by providing up to four senior sales reps, traders and senior management for face-to-face interviews individually. In return, they were promised a copy of the final report. Out of 45 financial firms, 25 agreed to participate in the research. The 20 firms that did not participate were all very small buy-side firms that declined because of a lack of resources.

Our subjects consisted of 90 senior managers, traders and sales reps from 25 financial institutions that represented both sell-side and buy-side. The financial institutions included seven major market-makers (i.e., sell-side), four medium- size sell-side, two major institutional investors (sell-side), four medium-size buy-side institutions, one IDB (inter-dealer broker) service provider, one ATS service provider and one major research boutique. Each interview, conducted by two of the authors, lasted from 60 to 120 minutes and was taped with the consent of interviewee. This enabled us to use the transcripts of the interviews for further analysis.

The procedure that we followed to collect the required data was as follows. First, a literature survey was performed to identify microlevel practices by the actors in the FI market. We used the multilevel organizational memory framework, proposed by Anand et al. [1], to depict the information flow and network ties among actors in the sell-side and buy-side FI market gleaned from various publications on the topic. Next, it was presented to a senior consultant, who had worked for more than 20 years in both buy-side and sell-side firms as a sales rep, to refine the depicted relationships as they 
pertain to practice. This made it possible to better understand the dynamics of relationships among the actors, and it prepared us to ask meaningful questions during our interviews with the subjects. During face-to-face interviews we asked each subject to walk through the information flow as it was depicted and explain the relationships among the actors in his or her firm. Subjects had the opportunity to make changes to the depicted information flow and to the relationships among actors. Figures $2 \& 3$ present the final outcome, showing information flow and network ties among actors in sell-side and buy-side respectively. We are confident that these figures correctly represent the microlevel structure of the FI market because 28 subjects at the end approved it without any change.

We also asked subjects to respond to a series of semi-structured questions related to the relational and cognitive dimension of their daily activities on the floor.

\section{Analysis}

\section{Network Ties analysis for Sell-side}

Figure 2 depicts network ties among actors from sell-side operational activities. All boxes but one are divided into two parts — Internal and external — representing within the sell-side firm and outside the firm (i.e. other sell-side, buy-side, govemment, news agencies).

Figure 2 about here

Let us start with the front-office. The primary responsibility of sales reps $\left[\mathrm{S}_{\mathrm{i}}\right]$ is to manage the relationship between the clients (large institutional investors such as Teachers and OMERS denoted by $\mathrm{B}_{1, \mathrm{i}}$ and small institutions denoted by $\mathrm{B}_{2, \mathrm{i}}$ and retail clients denoted by ${ }^{\mathrm{R}} \mathrm{C}_{\mathrm{i}}$ ) and dealers on the trading desk. The sales reps provide information to the client about the state of the market (market intelligence) and/or pass information to a specific trader at the desk if the client intends to buy/sell securities. Furthermore, sales reps also initiate daily contacts with "preferred clients" and each sales rep has embedded ties with up to 40 such clients who are considered profitable for the firm. The daily contacts 
enable the sales reps to keep track of clients' needs and provide them with market-intelligence, about the "breadth" of the market and if necessary provide further information about the "depth" of the market through traders at the trading desk. Large institutional clients, because of embedded ties with the dealers, enjoy the privilege of directly calling the trading desk by phone for consultation, negotiation and immediate execution of the order. This relationship with traders enables them to exchange private information such as depth of market, liquidity and effects of large transactions on the market. For example, traders as intermediaries may divide a large order into smaller lots for market offerings to avoid any adverse effect on their market (e.g. a \$500-million-dollar purchase of a specific bond can send an undesirable signal to the market causing a price increase). Here we see private information exchanged between client and trader with embedded ties to create information asymmetry for their mutual benefit. The relationship between small institutions and traders is usually at arm's-length, however. For example, the $\$ 1$ million purchase of a specific bond may not get the attention of a senior trader. As a result, a junior trader (or retail trading desk) would use alternative trading systems (ATSs) such as TradeWeb to purchase the bond for the client. The exception here arises when the client from a small institution contacts a trader with whom he or she has embedded ties. In this case, the client from the small institution can receive from the trader with embedded ties the same service as a large institution. It should be noted that institutional clients use a mix of embedded ties and arm's-length ties when contacting sales reps/traders. They use arm's-length ties to broker market differences by asking for "benchmark quotes" from sales reps belonging to different financial institutions. However, embedded ties are used to exchange detailed private in formation when the client asks for a "market quote" for an immediate transaction.

Sales reps use internal and external private and public information to serve their clients. Internal private information includes: Internal Research $\left[{ }^{\mathrm{I}} \mathrm{R}\right]$ (supplied by the firms' analysts), internal experts $\left[{ }^{\mathrm{I}} \mathrm{C}_{\mathrm{i}}\right]$ and Information created by different groups or departments $\left[{ }^{\mathrm{G}} \mathrm{I}_{\mathrm{i}}\right]$ (e.g., internal news, order flow and 
market intelligence). Thus, sales reps use direct ties with knowledge sources with in the firms to obtain internal private information. External Private Information gathered from external contacts [ ${ }^{\mathrm{E}} \mathrm{C}_{\mathrm{i}}$ ] (e.g. colleagues who might be working for other firms, and business acquaintances "in the know") through embedded ties with their contacts outside their firm. Internal public information is accessed through proprietary automated trading platform $\left[\mathrm{T}^{\mathrm{I}}\right]$ that supplies the firm's quotes and prices accessible internally to the traders and sales reps as well as externally to some of the clients. The external public information includes: market prices and news from public Info/data vendors $\left[{ }^{\mathrm{P}} \mathrm{I}_{\mathrm{i}}\right]$ (e.g. Reuters and Bloomberg), research boutiques [ ${ }^{\mathrm{E}} \mathrm{R}_{\mathrm{i}}$ ] (e.g. Action Economics, UFG Research) that the firms subscribe to and the external trading platform $\left[{ }^{\mathrm{E}} \mathrm{T}_{\mathrm{i}}^{\mathrm{P}}\right]$ (e.g. TradeWeb, eSpeed and CBID).

The traders at the trading desk also gather private and public information internally and externally. Internally, the trader has access to private information from: (a) direct ties with other traders at the desk $\left[{ }^{\mathrm{E}} \mathrm{D}_{\mathrm{i}}\right]$ (e.g., information about prices of other "related" bonds, market intelligence); (b) Direct ties with the firm's sales rep's private information $\left[S_{i}\right]$ (e.g., information about the firm's order flow and volumes for the current day); (c) Direct ties with senior management's private information $\left[{ }^{\mathrm{I}} \mathrm{C}_{\mathrm{i}}\right]$ (e.g., firm's guidance and policy, and expertise); and (d) Direct tie with the internal research unit and publications $\left[{ }^{\mathrm{I}} \mathrm{R}\right]$.

Externally, the trading desk has access to Inter-Dealers Brokers' markets [IDB ${ }_{\mathrm{i}}$. The IDB market is an "intermediate" and "live" market designed to facilitate trading between different dealerstraders who post bids and asks on individual securities on inter-dealers' screens for execution. The IDB's (e.g. Shorcan, Prebon, Cantor, Tullet and Freedom) enhance market liquidity by managing inventories from different traders/firms for a fee. The public information accessed through IDBs includes market prices, market supply and demand (indicated by the sizes of the Bids and Asks posted) from anonymous competitors. Traders use arm's-length ties with external dealers $\left[{ }^{\mathrm{E}} \mathrm{D}_{\mathrm{i}}\right]$ for a possible 
trade. Like sales reps, traders also have embedded ties with outside contacts $\left[{ }^{\mathrm{E}} \mathrm{C}_{\mathrm{i}}\right]$ such as colleagues in other financial institutions. Their external public information includes market prices and news from public Info/data vendors $\left[{ }^{\mathrm{P}} \mathrm{I}_{\mathrm{i}}\right]$ (e.g. Reuters and Bloomberg), research boutiques $\left[{ }^{\mathrm{E}} \mathrm{R}_{\mathrm{i}}\right]$ and the external trading platform $\left[{ }^{\mathrm{E}} \mathrm{T}_{\mathrm{i}}^{\mathrm{P}}\right]$ (e.g. TradeWeb, eSpeed and CBID).

Once a trade is executed, it is electronically reported to the back office by both the sales office and the trader. The back office is where all clearing and settlements occur. The back office is also divided into internal and external components. Internally, under the supervision of the firm, the back office performs the Inventory and Risk Management System [I/R] that keeps track of all the firm's trades. It performs an audit trail, verifies trades with counter parties, arranges for payments and settlement, and prepares electronic reports to the clients, sales office, trading desk, managers and regulatory authorities. A third-party sell-side custodian $\left[{ }^{\mathrm{S}} \mathrm{K}\right]$ is notified, either to deliver or to accept delivery if the firm sold or bought the security in question. Final clearing and settlement is done through an independent body called the "Canadian Depository for Securities" [CDS], established by the member brokerage houses. It is the common clearing and settlement link between the dealers and their clients (the buy and sell-sides) and between different dealers. A Private Clearing house [PC] that acts on behalf of the buy-side is also involved. The back office has access to all external market information, although only the risk and inventory system have access to the firm's internal private information (such as internal research and order flow). The back-office transaction is performed for the most part electronically, in which case it is called "straight-through processing". All the pertinent operations among actors here are direct ties for maximum transparency.

Risk Management, Compliance and Regulation divisions use all available information (public and private from within the firm) to oversee the operations of the firm (from the front to the back offices) plus all staff and client activities. These divisions are the custodians of the firm, dealing with issues such as the firm's overall risk exposure (market risk), credit compliance, compliance by staff and 
clients with the rules and regulations of the firm and industry. Here, relationships are direct ties with other actors in the firm for the sake of transparency and adherence to the rules and procedures that govern the operation of the firm.

\section{Network Ties analysis for Buy-Side}

Figure 3 depicts Information Flow and Network Ties among Actors in Buy-side FI market, and it is similar in design to Figure 2, all boxes but two being divided into two parts - Internal and External representing within the buy-side firm and outside the firm (sell-side, research boutiques, Govemment agencies...etc.). The first noticeable difference in Figure 3, however, is the absence of the front office. Typically the buy-side firms are private institutions representing one major client (like TEACHERS and OMERS) and are not in need of a sales office. Instead, the buy-side management is in charge of investment origination, ass et mix, trade execution and fund management.

Figure 3 about here

The management consists of a number of individuals with pre-assigned tasks, headed by a senior manager $\left[{ }^{\mathrm{S}} \mathrm{M}_{\mathrm{FI}}\right]$ who is ultimately responsible for the performance of the fixed-income portion of the fund. Other individuals include portfolio managers $\left[\mathrm{PM}_{\mathrm{i}}\right]$ who oversee different portions of the FI fund. Portfolio managers are the key players in the buy-side firms and are the focus of the sell-side daily contacts through embedded ties with sales reps $\left[\mathrm{S}_{\mathrm{i}}\right]$ and traders $\left[\mathrm{T}_{\mathrm{i}}\right]$. These contacts provide information (market intelligence ${ }^{1}$ ) beyond what is provided by the financial media (i.e., news/data vendors $\left[{ }^{\mathrm{P}} \mathrm{I}_{\mathrm{i}}\right]$ and research boutiques $\left.\left[{ }^{\mathrm{E}} \mathrm{R}_{\mathrm{i}}\right]\right)$. For example, sell-side sales reps provide "daily offering package"2 before the start of the trading day, or traders pitching trade ideas which may be based on recent market news. Typically, the day of a buy-side manager starts with the gathering of information. As one portfolio

\footnotetext{
${ }^{1}$ Nicknamed "market color".

${ }^{2}$ Daily roster of "specials" or available inventories of fixed income securities of a particular sell-side dealer (or their clients), the report can be either provided by email or over the phone. Large buy-side institutions receive the daily offerings report on a regular basis.
} 
manager commented "it starts with examining the daily offering package $\mathrm{e}^{3}$ and by morning calls to sales reps/dealers, surveying available securities". Portfolio managers (or their assistants) execute their own transactions. The bulk of trading is done over the phone (90\%); large buy-side firms prefer the direct contact with the sales reps/dealers, confidentiality being a major concern. However, this preference varies from firm to firm and from manager to manager. In selecting a dealer before a possible trade, PMs first "check the daily offering package" to select dealers with the desired inventory. Selection of a trading venue is governed by several concerns: liquidity of the issue, the dollar size of the trade, limit orders, additional trading information needed, user preference and confidentiality. ${ }^{4}$

Other actors on the buy-side desk include research Analysts/ Associate/ Assistants/Trainees ${ }^{5}\left[\mathrm{~A}_{\mathrm{i}}\right]$ and Quantitative Analysts $\left[\mathrm{A}_{i}{ }^{\mathrm{Q}}\right]$ in support of the portfolio managers. The $\mathrm{A}_{\mathrm{i}}$ 's are either assistants or junior portfolio managers performing research or ex ecution for the PM. These positions are created to provide additional research/info and serve as training ground for potential portfolio managers. The Quantitative Analysts assist portfolio mangers with the assessment of economic and industrial variables. Both $\mathrm{A}_{\mathrm{i}}^{\mathrm{Q}}$ and $\mathrm{A}_{\mathrm{i}}$ are located in close proximity to the PMs. This enables them to exchange information freely through direct ties among them.

Portfolio managers use internal and external private and public information in decision making. Internal private information includes: Internal in-house Research $\left[{ }^{\mathrm{I}} \mathrm{R}\right]$ supplied by the firms' analysts, internal experts $\left[{ }^{\mathrm{I}} \mathrm{C}_{\mathrm{i}}\right]$ and Pricing platform $\left[{ }^{\mathrm{G}} \mathrm{I}_{\mathrm{i}}\right]$ (e.g., CanPX, showing IDB market information: bid-ask, last trade, and volume). External Private Information is gathered through embedded ties with colleagues in other firms $\left[{ }^{\mathrm{E}} \mathrm{C}_{\mathrm{i}}\right]$, sell-side sales reps $\left[\mathrm{S}_{\mathrm{i}}\right]$ and traders $\left[\mathrm{T}_{\mathrm{i}}\right]$. Public information are accessed through

\footnotetext{
${ }^{3}$ From different dealers.

${ }^{4}$ The venue used depends primarily on the size of the trade: the smaller the size the more likely it is that it will be executed electronically. If additional information is needed regarding a trade, email or phone is used. Some portfolio managers may place "limit orders" with market makers via emails and ask for these orders to be filled once the limit price is reached. Liquidity is another major determinant of venue.

${ }^{5}$ Different buy-side firms use different designations.
} 
alternative trading systems $\left[{ }^{\mathrm{E}} \mathrm{T}_{\mathrm{i}}^{\mathrm{P}}\right]$ (e.g. Dealers' proprietary automated trading platform, TradeWeb, eSpeed and CBID), Info/data vendors [ ${ }^{\mathrm{P}} \mathrm{I}_{\mathrm{i}}$ ] (e.g. Reuters and Bloomberg), and research boutiques $\left[{ }^{\mathrm{E}} \mathrm{R}_{\mathrm{i}}\right.$ ] (e.g., Action Economics, UFG Research).

The middle of fice (i.e., Risk Management, Compliance and Regulation), through direct ties with management, uses available information to oversee the operations of the buy-side firm. This division is the internal custodian of the firm, overseeing staff compliance with the rules and regulations of the firm and industry. The middle office deals with the fund's overall exposure and required return, based on risk exposure parameters, to determine the required return from different portfolio managers.

The buy-side back office is divided into internal and external components. Internally, with direct ties with the middle of fice, it performs inventory and risk management through the Portfolio Management System [PMS] and the Portfolio Accounting System [PAS]. PAS performs an audit trail, verifies trades with counter parties (with the sell-side back office), arranges for payments and settlement, and prepares electronic reports to the PMS, which reports to upper-management and the portfolio managers. A third-party buy-side custodian $\left[{ }^{\mathrm{B}} \mathrm{K}\right]$ with arm's-length ties is notified, either to deliver or to accept delivery if the firm sold or bought the security in question. Final clearing and settlement is done through an independent body the "Canadian Depository for Securities" [CDS]. A Private Clearing house $[\mathrm{PC}]$ that acts on behalf of the buy-side is also involved.

\section{Network Configuration}

Information is the life-blood of the FI market operation, with benefits conting ent on access, timing and referrals. Access refers to receiving a valuable piece of information and knowing who can use it. This is particularly relevant in the FI market in which actors are unevenly connected with one another, are attentive to the information pertinent to the trade at hand, and are overwhelmed by the flow of public and private information. Traditional FI market trade is based on gatekeeper brokerage 
arrangements in which the embedded relationship between the sell-side and buy-side has facilitated an exchange of private information among actors to optimize mutual profits through embedded ties. Recent applications of electronic marketplace, however, have resulted in two complementary means of trade. On the one hand, liquid bonds — small lots of bonds - and/or products with little information asymmetry, such as foreign exchange, are traded through online systems or ATSs. This is where the retail trade benefits from market efficiency and from the transparency that the electronic marketplace provides. We see here brokerage arrangements with arm's-length relationships among the actors (Figure la). The liaison brokerage arrangement is also evident from inter-dealer brokerage systems (IDBs) that facilitate efficient transactions among traders who are well informed about the products traded. In other words, there is little information asymmetry among the dealers trading through IDBs. On the other hand, more than $80 \%$ of the volume of the total FI trade is done between institutional buyers and market-makers using the traditional gatekeeper brokerage arrangement (Figure 1b). They use the traditional telephone method of communication, relying on their embedded ties to use information asymmetry for mutual profit taking. As a result, use of information technology to mediate network relations would undermine the viability of the FI market's present business model.

\section{Network Structure}

Granovetter [20] theorized that weak ties are more likely than strong ties to be bridges to socially distant regions of a network and, therefore, new information. This is akin to the Burt's [9] structural hole that contends that in a network containing many "structural holes," it is easier to assimilate diverse resources and information. However, strong ties are believed to be instrumental in transferring tacit, complex knowledge among actors $[22,28]$. Our analysis shows that buy-side and sell-side actors in the FI market perform their daily transactions through both strong and weak ties as follows: 
The daily transactions between sell \& buy side begins with a "daily offering package" report sent from the sales reps (sell-side) to the major clients (i.e., institutional investors). The daily offering package contains a list of dealers' inventory as well as bonds that some of their clients wish to buy or sell anonymously. Each sales rep serves up to 40 portfolio managers of institutional investors. Sales reps may contact each client up to 35 times per day, mostly by phone to share proprietary information. Sales reps provide market intelligence to the portfolio managers and try to engage them to learn about possible new decisions (strategy) by the buy-side firms that may affect their portfolio mix (see Figure 4a). Thus, sales reps use strong ties with portfolio managers to share their tacit knowledge of the market intelligence with the portfolio managers and at the same time seek information from clients that may lead to sales. Furthermore, for new bonds, sales reps expect portfolio managers to act as a bridge to pass information to other pertinent decision makers (e.g. private investors that are clients of the institutional investors) for possible adoption.

The daily offering package provides a base for the portfolio managers to get a basic understanding of what is available in the market. They initiate contacts with sales reps and market makers when they wish to shop around and/or place an order for execution. For example, contact with sales reps is initiated when they wish to get an in-depth feel for the market (i.e. market intelligence) and/or receive benchmark price of a bond. In so doing, they expect to use sales reps as a bridge to receive inside information from market-makers; sell-side reports and management that may lead to execution of an order (see Figure 4b). Sales-reps may connect the client with a market maker if client requires more in depth information and/or wants to place an order. Significance of the information passed on to a client is a direct correlate of amount of ex ecution completed by the sell-side firm. Thus, to keep the sales reps engaged, institutional investors tend to place orders with different sell-side firms as needs arise. Small buy-side firms place their largest transactions with selected sales-reps to maintain embedded relationship for access to in-house information and "market intelligence". 
Market-makers are usually busy with executing large transactions. As a result, sales-reps may connect a client to a market-maker if the sales rep cannot satisfy the information requirements of the client who requires a significant transaction. Here, the sales reps are used as a bridge to link portfolio manger with a market-maker as shown in figure $4 \mathrm{~b}$. The portfolio manager may, however, also contact the market-maker (or ask a sales rep for a connection to a market maker) for immediate execution of a large order as depicted in Figure 4c. The communication between market maker and the portfolio manager is based on complete mutual trust: the client expects to receive the lowest price possible for the product, and market-maker expects that the client is firm in conducting the transaction immediately. This stage of communication is important for both sides: the market-maker shows his hand in regard to the price of the bond, and the client shows the amount of the specific bond that he or she is interested in. Therefore, the market-maker does not like to show his or her hand to a client who is not seriously considering placing an order. At the same time, the client, by announcing his or her need for a product, wants to purchase it as quickly as possible from the market-maker. If the client should decide to place the order with another firm, then the market-maker, knowing the needs of the client, can manipulate the market to market-maker's advantage. Although most of the contact with clients is done through sales reps, market-makers at times contact clients directly on special occasions that require immediate feedback (Figure 4d), such as:

I) To interest the client in a possible trade either as supplier of the bond (the market maker sold that bond to this client earlier).

II) To repurchase bonds from the client at a higher price than the earlier selling price because the market maker may have another client on the other end who is looking for a large transaction beyond his available inventory. In this case the market maker is shopping around to provide a client with a large order.

III) To provide information on the "breaking news" that could lead to a possible trade by the client.

IV) To receive information "market intelligence" from the client's point of view. 
Embedded ties between sell-side and buy-side, to exchange information within the framework of the gatekeeper brokerage arrangement, are based on interpersonal affect, trust, shared vocabulary and language [37], and these ties are discussed next.

Cognitive Dimensions consist of shared language and codes and shared narratives and metaphors among the market actors as follows:

Shared language and codes: Shared language and codes are essential to convey transaction information quickly and accurately between actors in the FI market (see Appendix A for a detailed scenario of a transaction between a buyer and seller). For example, the use of language and codes includes the terms such as: "on-the-run" and "off-the-run" bonds to distinguish between active/liquid issues and inactive/less liquid issues respectively. "I have an axe" or "I have no axe" are used to convey an interest or no interest respectively in the bonds that are about to be traded. Shared language and codes in the FI market evolve over time. For example, new expressions that may be unfamiliar to traders who retired a few years ago include: "custody holdings" and "maple bonds". The former refers to Federal Reserve holdings on behalf of foreign central banks in the US, and "maple bonds" refer to the issuance of new foreign bonds in Canada.

Shared narratives and Metaphors: Shared narratives and metaphors are in used in the FI market to share information accurately without having to go into detail, such as "market color" (see Appendix A). For example, "the market feels clean" means that there seem to be no products for sale at this moment or "everybody is clean" signifies that the dealers are out of inventory of a particular bond. This implicitly signifies that the market is expected to keep bidding up the prices to entice sellers into the market. Another example is "No one is long" -- indicating that dealers have no inventory. The "street is heavy" means that the dealers are carrying a significant amount of inventory and would like to sell them (lighten their load of bond inventory), but there are no buyers around. The "street is short" has the opposite 
meaning; it signifies that the dealers are light on inventory and would like to buy but there are no sellers around.

The cognitive dimension helps the actors to communicate effectively and efficiently with each other. However, the relational dimension interaction among the market actors is based on well defined code of conducts that governs the FI market to function efficiently, as follows.

\section{Relational Dimension}

Trust: The basic view of actors in the FI market is summarized in their motto "my word is my bond" that refers to trust in "reliability, capability, and competence" of the trading partners. For example, when a trader buys bonds, the trader is expected to accept delivery at an agreed price and is capable of due payment in a timely fashion. Competence implies professionalism in conducting transactions at the best available rate and sticking to the code of conduct. For example, one sales rep commented that " $m y$ loyalty is to my clients and the firm". Occasionally, these loyalties might be at odds with each other. A case in point is the dilemma faced by a sales rep who has to choose between loyalty to the client and loyalty to his own firm when faced with the following scenario. A client might confide to a sales rep that his firm has a large selling program that often involves a number of issues amounting to billions of dollars that can be completed over a specified period of time. The sales rep, after receiving this confidential information from the client, notices that one of his or her traders intends to aggressively buy up one of the bonds that his client intends to dump onto the market. The sales rep faces an ethical dilemma here. He/she cannot divulge the information to his trader and at the same time he/she cannot stand by and see his/her firm lose money. The situation might be handled as follows: he might tell the trader "are you sure that you want to buy this bond" or "I wouldn't buy that bond right now". An experienced trader immediately understands what the sales rep is trying to communicate: don't buy the specific bond right now because someone is going to sell a large amount of it in the near future. The 
trader also knows that no further details should be asked of the sales rep because of customer confidentiality.

Norms: The general norm is to act in a professional manner in the FI market. Professionalism is expected from all the actors since the action of one player has a direct impact on the well being of others. For example, the FI actors are rewarded based on their own individual performance as well their group performance in the firm. Thus, there is little tolerance for poor performance. Since the actions of others outside the firm can also affect one's performance, professionalism is therefore expected from outside actors as well. For example, when a market-maker buys a large amount of bonds from a client, it is expected that the client will follow certain implicit norms as follows: first, the market-maker expects that the client has given him his entire order, especially if the market-maker has accommodated the client's needs well. Second, the market-maker expects the client to keep the transaction confidential. Third, the market-maker expects that the client will allow ample time for the rebalancing of books before trading in the same security again.

Obligation and expectations: As pointed out before, FI actors expect professionalism and courtesy from each other in their daily activities. They are expected live to the motto of "my word is my bond" (once they say "done" regarding a trade, they are not expected to go back on their word) and to respect market norm. Buyers expected to receive market information from the sales reps and market makers. Sellers in return expect to receive orders from the buyers. As one sales rep commented "it's a give and take game like a poker game. You need to keep the information close to your chest and 'trade' it to get more information." Sellers and buyers assume different obligations depending on the type of information they expect to exchange. Buyers call different sales reps to receive market intelligence that includes market quote and market flow. When a client asks for the market price of a bond, however, it is understood that the buyer is obliged to accept the deal (see Appendix A for detailed example). On the other hand, the client expects the market maker to give the best deal possible. Sales reps are also 
expected to contact the clients to provide pertinent market information. In return, sales reps expect to receive orders from their clients, otherwise, their contact with them will drop significantly. These reciprocal obligations are a market norm that provides prosperity to both buyers and sellers and enables the FI market to function.

Identification: There are no official groups or subgroups that the FI actors belong to. They come from all walks of life. Most portfolio managers and some traders have acquired the designation of CFA (chartered financial analyst) and belong to their local chapter (e.g. the Toronto Society of Financial Analysts has about 4,000 members and is the second largest in the world after New York Financial Analysts' Society). Most of the FI functions (e.g., luncheons and dinners) are geared for sales reps and clients to attend. However, occasionally a trader is asked to join a function with a potential institutional client and to introduce the client face-to-face to the trader who will be handling the client's business. Acceptance in the FI business is done through reputation in daily transactions. The trader is expected to be a capable person, hardworking, able to deal with failure and to recoup, and able also to interact with others in a respectful manner. The position/job "norm" is learned through mentorship and through observing others as they work their way through the ranks. This is in addition to in-house training and mentorship programs for new recruits who usually come from reputable academic institutions.

\section{Discussion}

The objective of this study was to explore the ways information flow mediates brokerage relationships that are enacted through interaction of actors in the FI market and assess its effect on the use of electronic trading systems. Essentially, these relations instantiated daily, are by and large embedded to deal with mutual need of the actors for private information to maximize their profitable transactions. The basic need for embedded relationships among actors is to deal with information asymmetry for mutual profit taking. To this end, more than $90 \%$ of FI transactions in volume are done by phone. 
However, to improve distribution of information, digital economy encourages the creation of institutional structures that assure online inter-organizational exchange relationships.

There is no shortage of alternative trading systems in the FI market place. More than 23 different ATS platforms are used internationally to support different types of FI trade. These ATSs, such as TradeWeb, are notably characterized by: (a) the impersonal nature of the online environment and (b) the extensive use of communication technology as opposed to other modes of transactions, such as face-to-face and telephone. Arms-length relationships are well supported through information technology such as straight-through processing for back-office processing or acquisition public data from Bloomberg or Reuters. The question arises as to why ATSs have not replaced traditional methods of phone transactions in the FI market to trade. Characteristics of the brokering arrangement are central to this question: Sell-side and buy-side are engaged in embedded "gatekeeper" brokerage relationships to benefit from FI market information asymmetry.

There is a general agreement that informed traders exploit their informational advantage and trade optimally to profit from uninformed investors $[17,30,48]$. Therefore, as we have noted in our investigation, the institutional investors use embedded direct ties with market-makers to access private information and negotiate preferential trade for large transactions over the phone. Time is very much of the essence in negotiating bond prices for large transactions, and exchange of tacit knowledge by the actors must be completed within seconds through a communication medium with a high social presence. Social presence is defined as "the degree to which the medium facilitates awareness of other person and interpersonal relationships during the interaction" [14, p.118]. On the one hand, when a task is interpersonal, as in a negotiation of pricing bond, real-time synchronous media with a high social presence such as face-to-face or phone interaction are deemed the most appropriate choice[41] . Therefore, telephone communication is the most suitable medium to negotiate large transactions in the FI market because of the geographical distance between institutional investors and market-makers. On 
the other hand, online trading systems such as TradeWeb become a suitable means of transaction for small trades when there is no room for negotiation. IDB systems are also favored for transactions because there is little information asymmetry among the participants who are representatives of the market-makers. The sellers provide closure by posting the price and quantity of their bonds on the trading system, in either of these two latter cases.

Our analysis of microlevel practices and social interaction of the actors in the secondary FI market is the first attempt to understand the macrolevel practices of the buyer and sellers to perform their daily transactions. Our findings, based on face-to-face semi-structured interviews with the actors, reveal the reason behind low-level use of ATS.

\section{Implication for Practice and Research}

There has been a successive forecast over the past twenty years in business media that technology would catch up in automating FI transaction $[12,42]$. This has not been materialized. There is no doubt that usage improves as ATS become better integrated with other information systems within and between the financial firms. However, our analysis of microlevel practices and social interaction among the FI actors shows that the major players, that constitute market-makers and institutional investors, have developed a strong social network to exchange private information and to benefit from the information asymmetry inherent in the market. Investment in social relations with expected returns is captured under the rubric of social capital. Social capital owned by the FI firms in effect governs $95 \%$ of FI transactions in volume. Therefore, it is necessary to support this social relation with appropriate technologies. Otherwise, replacing it with ATS can have dysfunctional effect on the present market structure. This is because a change in an organization's technology entails adjusting the tools, devices, knowledge, or techniques that create new products or services [43]. 
Technological change can be classified as competence-enhancing or competence-destroying. Competence-enhancing adjustments that build on existing know-how within the organization tend to consolidate industry leadership: "the rich get richer" [43, p. 460]. In contrast, the introduction of fundamentally different technologies or competence-destroying discontinuities is associated with major changes in the distribution of power and control $[8,29,39]$. Competence-destroying discontinuities disrupt industry structure [34]. For example, a recent investigation by Schultz and Orlikowski [39] shows that the use of self-serve technology made it more difficult for sales reps to build and maintain embedded relationships with their customers with consequent adverse effects on the social capital of the firm. Similarly, use of ATS for large transactions would have an adverse effect on the social relations and profitable transactions among FI actors. Thus, we need supporting technologies, such as knowledge management, to improve relational network among the actors and optimize the social capital of FI firms. For example, data mining can be used to match products and information to the needs of individual buyers.

Mismatch of task-technology adversely affects operational efficiencies. This is well documented in the literature $[15,23,41]$. Yet, we witness disregard for it when it comes to implementation of technology. This is partly due to the hasty decision by management to automate routine transactions without paying attention to the nature of the social network embedded within the transaction [39]. The problem is also related to a lack of metrics to assess the worth of social capital and of social networks among the cooperating firms [26], making it difficult to explicitly assess cost-benefit of IT to mediate network relations.

The 45- trillion-dollar size of the FI market makes it significant enough to merit the attention of IS scholars to help financial firms adopt information technology in an "appropriate" manner for improved efficiency and effectiveness in the market place. Detailed analysis of information requirements and of social network structure can provide us with the requisite knowledge of the 
transition of the FI market to the electronic marketplace in our quest for improved market efficiencies.

The analysis of F I market information flow and network ties detailed in this paper provides a first step in this endeavor.

\section{References}

1. Anand, V., Manz, C.C., and Glick, W.H. An organizational memory approach to information management. Academy of Management Review, 23, 4, (October 1998), 796-809.

2. Abolafia, M.Y. Making Markets: Opportunism And Restrain On Wall Street. Harvard Business Press, Cambridge, MA, 1997.

3. Adler, P.S. Market, hierarchy and trust: the knowledge economy and the future of capitalism. Organizational Science, 12, 2 (2001), 215-234.

4. Bakos, J.Y. The emerging role of marketplaces on the internet. Communications of the ACM, 41, 8, (August 1998), 35-42.

5. Bakos, J.Y. Reducing buyer search costs: implications for electronic marketplaces. Management Science, 43, 12, (1997), 1676-1692.

6. Bakos, J.Y., Lucas, Jr. H.C., Oh, W., Simon, G., Viswanathan, S., and Weber, B.W. The impact of E-commerce on competition in the retail brokerage industry. Information Systems Research, 16, 4, (December 2005), 352-371.

7. Borgatti S., Cross R. A relational view of information seeking and learning in social networks. Management Science, 49, 4, (April 2003), 432-445.

8. Burkhardt, M.E. and Brass, D.J. Changing patterns or patterns of change: the effects of a change in technology on social network structure and power. Administrative Science Quarterly, 35, 1, (March 1990), 104-127.

9. Burt R. Structural Holes; Social Structure Of Competition, Harvard University Press, 1992.

10. Chakraborty A., Yilmaz B. Manipulation in market order models. Journal of Financial Markets, 7 , (2004), 187-206.

11. Coleman, J.S. Social capital in the creation of human capital. American Journal of Sociology, 94, (1988), S95-S120.

12. Collins, A.L. Regulation of alternative trading systems: evolving regulatory models and prospects for increased regulatory coordination and convergence. Law and Policy in International Business, 33, 3, (Spring 2002), 481-506.

13. Doney, P.M. and Cannon, J.P. An examination of the nature of trust in buyer-seller relationships. Journal of Marketing, 61, 2, (April 1997), 35-51.

14. Fulk, J., Schmitz, J. and Steinfield, C.W. A Social Influence Model of Technology use," in Fulk, J., Steinfield, C. (eds.) Newbury Park, CT, 1990, 117-142.

15. Fulk, J., Steinfield, C.W., Schmitz, J., and Power, G.J. A social information processing model of media use in organizations. Communication Research, 14, 5, (1987), 520-552. 
16. Gallaugher J. Market formation and fixed income e-commerce. Journal of Electronic Commerce Research, 3, 2, (2002), 50-58.

17. Glosten, L.R., Harris, L.E. Estimating the components of the bid/ask spread. Journal of Financial Economics, 21, (1988), 123-142.

18. Gould R.V. and Fernandez, R.M. Structure of mediation: a formal approach to brokerage in transaction networks. Sociological Methodology, 19, (1989), 89-126.

19. Granovetter M. Economic action and social structure: the problem of embeddedness. American Journal of Sociology, 91,3, (Nov. 1985), 481-510.

20. Granovetter M. The strength of weak ties. American Journal of Sociology, 78, 6, (May 1973), 13601380.

21. Gulati, R. Social Structure and alliance formation patterns: a longitudinal analysis. Administrative Science Quarterly, 40, (1995), 619-652.

22. Hansen M. The search-transfer problem: the role of weak ties in sharing knowledge across organization subunits. Administrative Science Quarterly, 44, 1, (March 1999), 82-111.

23. Irani, Z, Sharif, A.M and Love P.E.D. Transforming failure into success through organizational learning: an analysis of a manufacturing information system. European Journal of Information Systems, 10, 1, (2001), 55-66.

24. Jack S. The role, use, and activation of strong and weak network ties: a qualitative analysis. Journal of Management Studies, 42, 6, (September 2005), 1233-1259.

25. Konana, P., Menon, N.M., and Balasubramanian, S. The implications of online investing. Communications of the ACM, 43, 1, (January 2000), 35-41.

26. Kogut, B. The network as knowledge: generative rules and the emergence of structure. Strategic Management Journal, 21, 3, (March 2000), 405-425.

27. Koski, J.L. and Michaely, R. Price, liquidity, and the information content of trades. The Review of Financial Studies, 13, 3, (Autumn 2000), 659-696.

28. Krackhardt, D. The strength of Strong ties: The Importance of Philos. In N. Nohria and R. Eccles (Eds) Networks and Organizations: Structures, Forms and Action. Harvard Business Press, Boston, MA, 1992, pp.216-239.

29. Lapointe, L. and Rivard, S. A multilevel of resistance to information technology implementation. MIS Quarterly, 29, 30, (September 2005), 461-491.

30. Madhavan, A., Smidt, S. An analysis of changes in specialist inventories and quotations. Journal of Finance, 48, (1993), 1595-1628.

31. Marsden, P.V. Brokerage Behavior in Restricted Exchange Network. In Marsden, P.V. and Lin, N. (Eds) Social Structure and Network Analysis, Bervferly Hills:Sage, 1982, pp. 201-219.

32. Marsden, P.V. Introducing influence processes into a system of collective decisions. American Journal of Sociology, 86, (1981), 1203-1235.

33. Mendelson H., Tunca T. Strategic trading, liquidity, and information acquisition. The Review of Financial Studies, 17, 2, (2004).

34. Mensch, G. Statement In Technology: Innovations Overcome The Depression. Ballinger, Cambridge, MA, 1979. 
35. Montazemi, A.R., Siam, J. State of information technology support for traders in fixed-income market. Proceedings of the Eleventh Americas Conference on Information Systems, Omaha, NE, August 11-14, 2005.

36. Moulton A., Bressan S., Madnick S., Siegel M. Using an active conceptual model for mediating analytic information interchange in the fixed income securities industry. MIT Sloan School of Management working paper Sloan WP\#4023, April 1998.

37. Nahapiet, J. and Ghoshal, S. Social capital, intellectual capital, and the organizational advantage. Academy of Management Review, 23, 2, (April 1998), 242-266.

38. Podolny J., Baron J. Resources and relationships: social networks and mobility in the workplace. American Sociological Review, 62, (October 1997), 673-693.

39. Schultz, U. and Orlikowski, W. A practice perspective on technology-mediated network relations: the use of internet-based self-serve technologies. Information Systems Research, 15, 1, (March 2004), 87-106.

40. Shane S., Cable D. Network ties, reputations, and the financing of new ventures. Management Science, 48, 3, (March 2002), 364-381.

41. Straub, D. and Karahanna, E. Knowledge worker communications and recipient availability: toward a task closure explanation of media choice. Organization Science, 9, 2, (March-April 1998), 160175.

42. The Bond Market Association. E-commerce in the fixed-income markets: the 2006 review of electronic transaction systems. (2006), www.bondmarkets.com.

43. Tushman, M.L. and Anderson, P. Technological discountinuties and organizational environment. Administrative Science Quarterly, 31, (1986), 439-465.

44. Uzzi, B. Embeddedness in the making of financial capital: how social relations and networks benefit firms seeking financing. American Sociological Review, 64, 4, (August 1999), 481-505.

45. Uzzi, B. The sources and consequences of embeddedness for the economic performance of organizations. American Sociological Review, 61, (1996), 674-698.

46. Uzzi B., Gillespie J. Knowledge spillover in corporate financing networks: embeddedness and the firm's debt performance. Strategic Management Journal, 23, 7, (March 2002), 595-618.

47. Uzzi B., Lancaster R. Relational embeddedness and learning: the case of bank loan managers and their clients. Management Science, 49, 4, (April 2003), 383-399.

48. Wang, J. A model of intertemporal asset prices under asymmetric information. Review of Economic Studies, 60, (1993), 249-282.

49. Weber, B.W. Adoption of electronic trading at the international securities exchange. Decision Support Systems, 41, 4, (2006), 728-746.

50. Weber, B.W. Next-gen eration trading in futures market: a comparison of open outcry and order matching systems. Journal of Management Information Systems, 16, 2, (Fall 1999), 29-45.

51. Xiao Z., Powell P., Dogson J. The impact of information technology on information asymmetry. European Journal of Information Systems, 7, 2, (June 1998), pp.77-89. 


\section{Appendix A}

\section{Institutional Client/Dealer Trade Phone Transaction}

The following scenario is a telephone conversation between an institutional client (IC) called Dave, and a market-maker/dealer (MM) called Joe which highlights some of the shared language and codes used in the FI market:

\section{Background}

Dave, who is an institutional client, intends to buy $\$ 200$ million of Govemment of Canada (GC) 10-year $8 \%$ bond. He checks the quotes on the Bloomberg screen and finds that the best quote on GC 10-year is offered by Joe of XYZ firm and is $\$ 145.34$ / \$145.44 with maximum size of 5 X 5 (i.e. $\$ 5$ million on the bid side by $\$ 5$ million on the offer side). This translates into the quoted bid price where Dave can immediately sell $\$ 5$ million at $\$ 145.34$ (per $\$ 100$ face value) and quoted offered price where Dave can immediately buy $\$ 5$ million at $\$ 145.44$ (per $\$ 100$ Par value). Dave knows that this screen quoted price and sizes is a benchmark that can be used as the base to negotiate orders larger than $\$ 5$ million. He calls Joe the market-maker for a possible trade. The scenario presented below highlights the interaction between Dave and Joe which results in the completion of more than $\$ 290$ million transaction over the phone within a few seconds.

\begin{tabular}{|c|c|}
\hline $\begin{array}{c}\text { A typical FI transaction scenario by phone } \\
\text { (IC: Institutional Client, MM: Market Maker/Dealer) }\end{array}$ \\
\hline Actual Dialogue & \multicolumn{1}{|c|}{ Translation } \\
\hline IC: Hey Joe; how's the Client is trying to receive market intelligence on the \\
$\begin{array}{l}\text { market on the long } \\
\text { end? }\end{array}$ & $\begin{array}{l}\text { segment of the bond market he is interested in (i.e. the } \\
\text { supply and demand on the GC 10-year). However, he } \\
\text { doesn't want to show his intention (not yet) and asks "how } \\
\text { is the long end of the bond market" that covers bonds with }\end{array}$ \\
\hline
\end{tabular}




\begin{tabular}{|c|c|}
\hline & long maturity from 10 -year to 30 -year bonds. \\
\hline \multicolumn{2}{|c|}{$\begin{array}{l}\text { MM: Hi Dave, the markete market-maker recognizes the caller is David as one of his } \\
\text { feels clean. What do regular clients, and conveys to him his impression of the } \\
\text { want to do? } \\
\begin{array}{l}\text { current status of the market for long-term bonds. The } \\
\text { market "feels" clean because there is no major seller in the } \\
\text { market. Then he asks about Dave's intention: whether he } \\
\text { is a buyer or a seller. }\end{array}\end{array}$} \\
\hline \multicolumn{2}{|c|}{$\begin{array}{l}\text { IC: I have an axe on 10s.e client pointed the market-maker in the direction of his } \\
\text { What's your market? } \\
\text { interest and asks for his bid and offer on the Government of } \\
\text { Canada 10-year bond (10s). By using the coded word } \\
\text { "market" instead of "benchmark quote or quote" the client } \\
\text { conveys his seriousness about the upcoming transaction } \\
\text { and shows he is not just window-shopping. In addition, the } \\
\text { client asks for the market and not where he can buy the } \\
\text { bonds; he still has not "revealed" his true intention to the } \\
\text { MM. }\end{array}$} \\
\hline MM: 37 to 42,25 up & $\begin{array}{l}\text { The market maker acknowledges that the } \\
\text { buyer is serious and "tightens" his } \\
\text { market spread to } \$ 145.37 \text { / } \$ 145.42 \\
\text { and in addition increases his quoted } \\
\text { size to } \$ 25 \text { million on both sides of the } \\
\text { bid and offer to } \$ 25 \text { Million (the word } \\
\text { "up" conveys that). Furthermore, there } \\
\text { is no need to spell out the whole price } \\
\text { value (i.e., } 37 \text { instead of } \$ 145.37 \text { ) } \\
\text { because both are familiar with the } \\
\text { industry's shared language and codes. } \\
\text { To speed up the transaction only the } \\
\text { last two digits are used. In addition, } \\
\text { there is no need to say millions; at the } \\
\text { institutional desk it is a given (unless } \\
\text { otherwise stated). The smallest trading } \\
\text { volume increment is } \$ 1 \text { million and any } \\
\text { order less than } \$ 1 \text { million face value is } \\
\text { considered an odd lot. }\end{array}$ \\
\hline IC: I'm 39 bid & $\begin{array}{l}\text { At this point the client reveals his true } \\
\text { intention and declares that he is } \\
\text { prepared to pay } \$ 145.39 \text { for the bond. } \\
\text { Note that the quantity has not been } \\
\text { discussed yet. }\end{array}$ \\
\hline MM: Ok, sell 25 at 39 & $\begin{array}{l}\text { At this bid the market maker is prepared to } \\
\text { supply } \$ 25 \text { million to the IC. }\end{array}$ \\
\hline $\begin{array}{l}\text { IC: I bought them, Keep } \\
\text { going }\end{array}$ & $\begin{array}{l}\text { This tells the MM that the client bought } \$ 25 \\
\text { million and is interested in buying more } \\
\text { bonds. }\end{array}$ \\
\hline $\begin{array}{l}\text { MM: What's your total } \\
\text { interest }\end{array}$ & $\begin{array}{l}\text { At this point, the MM understands that the } \\
\text { client wants to purchase more than } \$ 25 \\
\text { million. Therefore, he tries "to size" the } \\
\text { client to see how large the order is. It } \\
\text { also "let's get down to business and I } \\
\text { will try my best to accommodate you." }\end{array}$ \\
\hline IC: I can buy another 175 & $\begin{array}{l}\text { Based on their past experience Joe and } \\
\text { David have developed a degree of }\end{array}$ \\
\hline
\end{tabular}




\begin{tabular}{|c|c|}
\hline & $\begin{array}{l}\text { trust, and at this point Joe reveals his } \\
\text { remaining total quantity desired which } \\
\text { is } \$ 175 \text { million. }\end{array}$ \\
\hline $\begin{array}{l}\text { MM: } 75 \text { will come at } 41 \\
\text { and the balance will } \\
\text { come at } 42 \text {. As long } \\
\text { as, you don't get in } \\
\text { my face. }\end{array}$ & $\begin{array}{l}\text { The market maker tells the client he is } \\
\text { ready to offer him } \$ 75 \text { million at } \\
\$ 145.41 \text {, and the reminder of his order } \\
\text { (i.e., } \$ 100 \text { million) at } \$ 145.42 \text {. The } \\
\text { statement "as long as, you don't get in } \\
\text { my face" means that "I am going short } \\
\text { on the "10s" to accommodate you. } \\
\text { Therefore, I need to replenish my } \\
\text { inventory in the market. You should } \\
\text { give me some time to do so, and I } \\
\text { wouldn't be happy to find out that you } \\
\text { are trying to buy more "10s" from } \\
\text { another dealer. If you have more to buy } \\
\text { this is the time to come clean." }\end{array}$ \\
\hline IC: that seems dear & $\begin{array}{l}\text { At this point Joe knows that he can } \\
\text { purchase the } \$ 200 \text { million from David. } \\
\text { However, Joe tries to "shave" some } \\
\text { pennies off the price (reduce the price). }\end{array}$ \\
\hline $\begin{array}{l}\text { MM: a lot of interest on } \\
10 \text { s. And the street is } \\
\text { light. }\end{array}$ & $\begin{array}{l}\text { I have other buyers interested in these } \\
\text { bonds. Given the current market that is } \\
\text { the best I can do for you right now. } \\
\text { There are no large sellers in the market } \\
\text { and inventory is scarce. }\end{array}$ \\
\hline IC: OK, done. & The client agrees and the trade is done. \\
\hline $\begin{array}{l}\text { MM: OK, you paid } 39 \text { for } \\
25,41 \text { for } 75 \text {, and } 42 \\
\text { for } 100 .\end{array}$ & $\begin{array}{l}\text { The MM recaps the order. So you paid } \\
\$ 145.39 \text { for } \$ 25 \text { million, } \$ 145.41 \text { for } \\
\$ 75 \text { million and } \$ 145.42 \text { for } \$ 100 \\
\text { million. }\end{array}$ \\
\hline IC: Right & $\begin{array}{l}\text { The client confirms and the contract is } \\
\text { binding on both parties (phone } \\
\text { conversations are recorded) and both } \\
\text { back offices (the sell and the buy side) } \\
\text { take over to complete payment and } \\
\text { settlement of the transaction. }\end{array}$ \\
\hline $\begin{array}{l}\text { MM: Thanks for the } \\
\text { business. }\end{array}$ & Thank you and come again. \\
\hline
\end{tabular}

Because of shared language and codes, the two parties were able to complete a transaction valued at $\$ 290,825,000$ within seconds. 
Figure 1

Brokerage arrangement and network relations adapted from [39]

(a) Liaison Brokerage Arrangement and Arm's-Length Relations

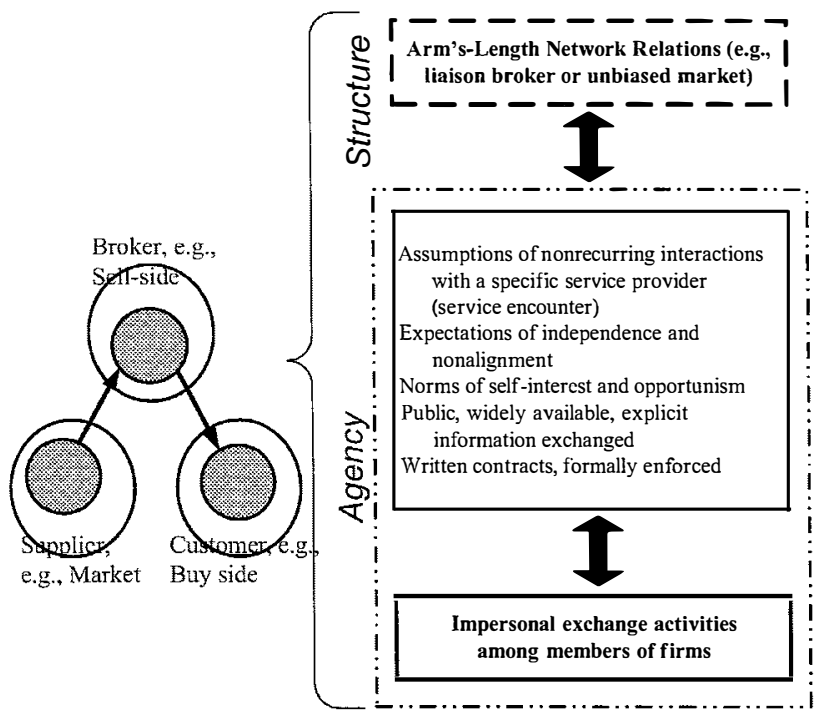

(b) Gate Keeper Brokerage and Embedded Relations

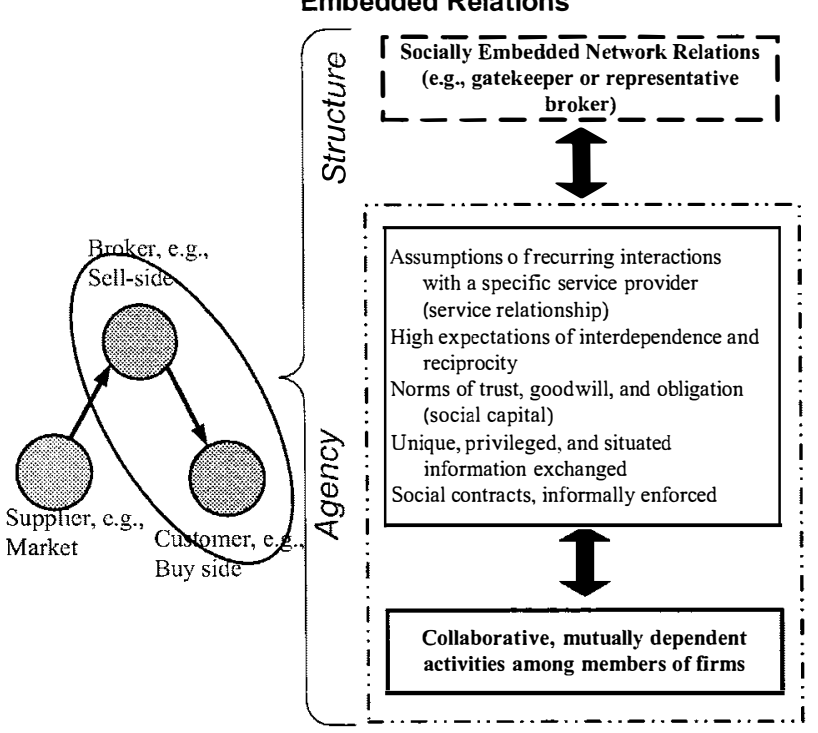


Figure 2: Information Flow and Network Ties among Actors in Sell-Side FI market (I stand for Internal and $\mathrm{E}$ for external. See Table 1 for details)

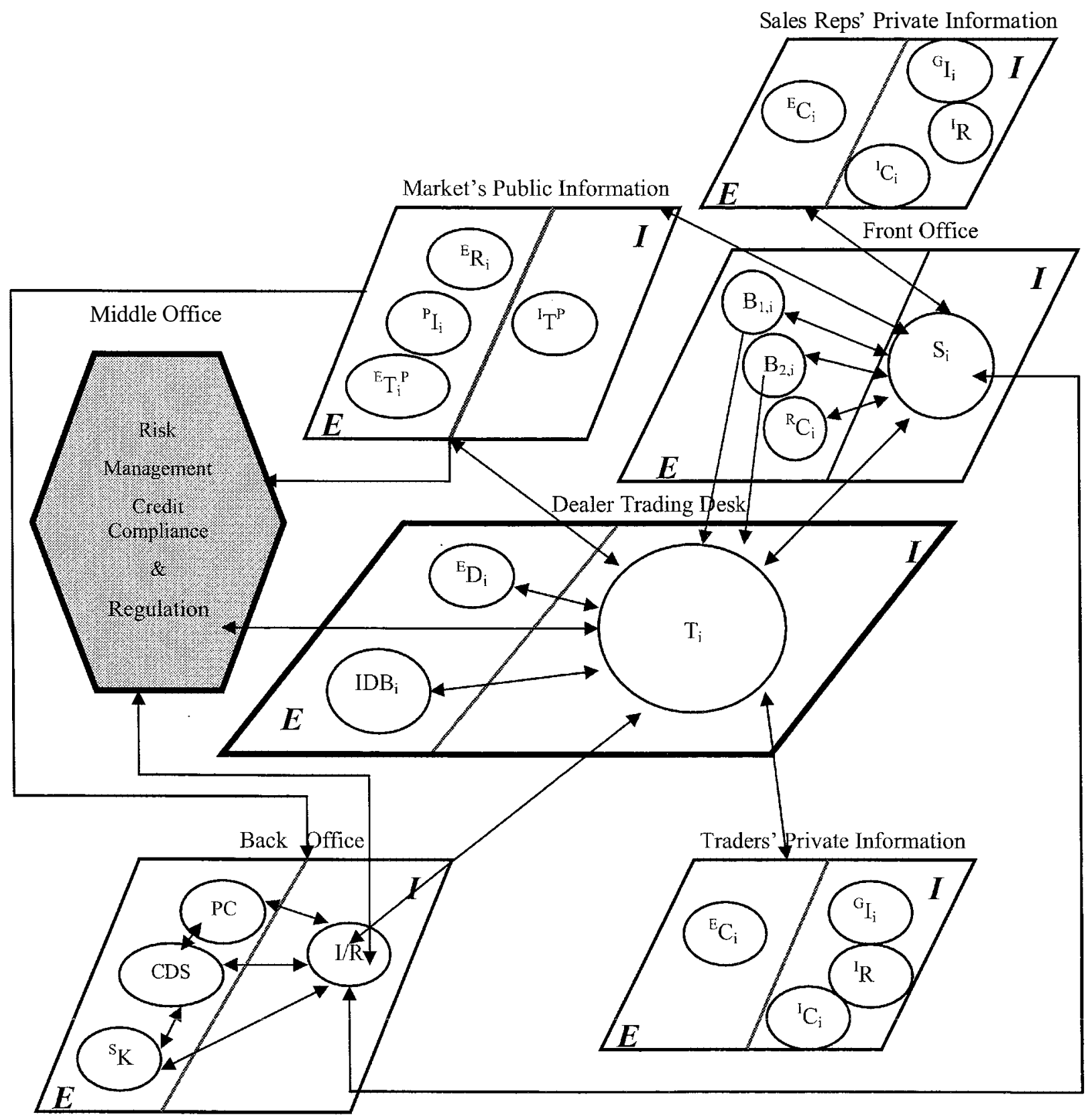


Figure 3: Information Flow and Network Ties among Actors in Buy-Side FI market (I stands for Internal and E for external. See Table 2 for details)

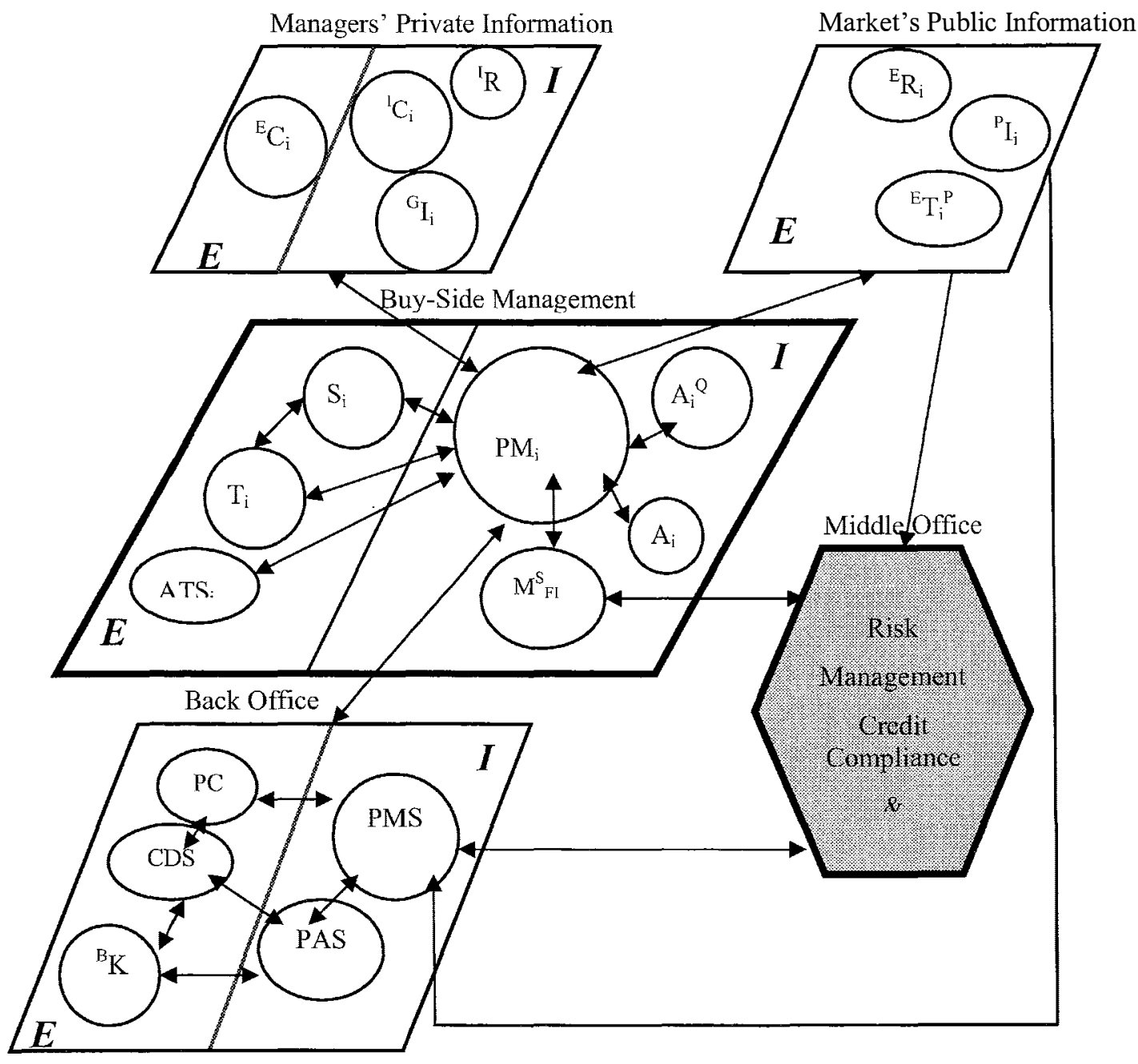


Figure 4: Network structure among actors in FI market

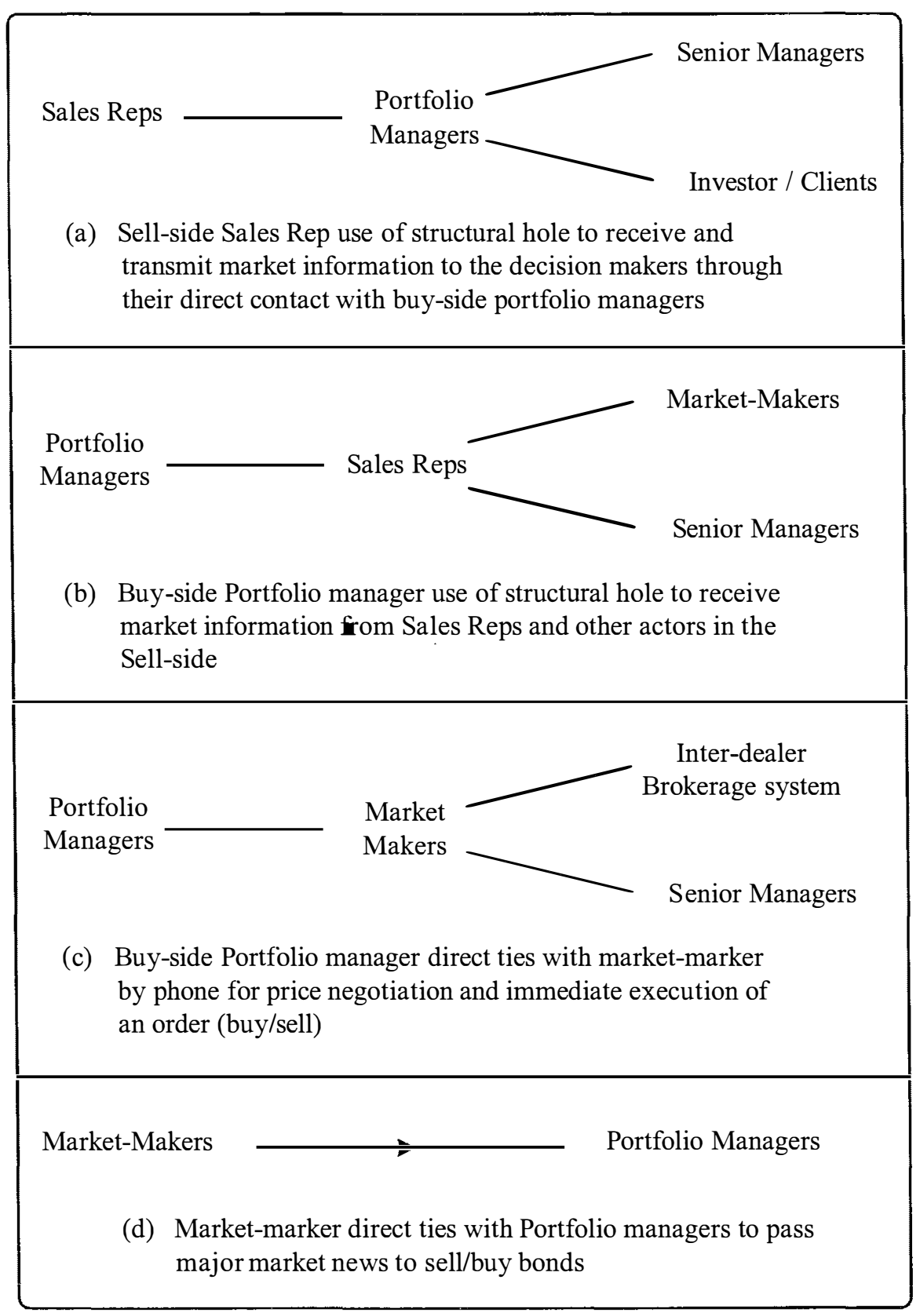


Table 1: Legend for Figure 2

\begin{tabular}{|c|c|c|}
\hline Description & Internal & External \\
\hline $\begin{array}{c}\text { Sales Office } \\
\{\text { Front Office }\}\end{array}$ & $\begin{array}{c}\mathrm{S}_{\mathrm{i}}: \text { Fixed income sales force, } \\
\text { including the retail sales } \\
\text { force (Sales/Traders) }\end{array}$ & $\begin{aligned} & \mathrm{B}_{1, \mathrm{i}} \text { Large buy-side institutional } \\
& \text { Firms } \\
& \mathrm{B}_{2, \mathrm{i}} \text { Small buy-side Institutional } \\
& \text { firms } \\
&{ }^{\mathrm{R}} \mathrm{C}_{\mathrm{i}} \text { : Retail clients }\end{aligned}$ \\
\hline Dealer trading desk & $\begin{array}{c}\mathrm{T}_{\mathrm{i}}: \text { Sell-side market makers or } \\
\text { Traders, including the } \\
\text { senior trader/manager } \\
\text { (VP trading) }\end{array}$ & $\begin{array}{ll}\mathrm{IDB}_{\mathrm{i}} & : \text { Inter-Dealers Brokers } \\
{ }^{\mathrm{E}} \mathrm{D}_{\mathrm{i}} & : \text { Other dealers } \\
\mathrm{C}_{\mathrm{i}} & : \text { Contacts }\end{array}$ \\
\hline $\begin{array}{l}\text { Sales reps' \& traders' } \\
\text { private information }\end{array}$ & $\begin{aligned}{ }^{\mathrm{I}} \mathrm{R}: \text { Internal research } \\
{ }^{\mathrm{I}} \mathrm{C}_{\mathrm{i}}: \text { Internal contacts } \\
{ }^{\mathrm{G}} \mathrm{I}_{\mathrm{i}}: \text { Internal news, order flow and } \\
\quad \text { market intelligence }\end{aligned}$ & ${ }^{\mathrm{E}} \mathrm{C}_{\mathrm{i}}$ : External contacts \\
\hline Market's public information & $\begin{aligned}{ }^{\mathrm{T}} \mathrm{T}^{\mathrm{P}}: & \text { Proprietary automated trading } \\
& \text { platform }\end{aligned}$ & $\begin{array}{l}{ }^{{ }^{\mathrm{P}}} \mathrm{I}_{\mathrm{i}}: \text { Public Info from vendors } \\
{ }^{\mathrm{E}} \mathrm{R}_{\mathrm{i}}: \text { External research boutiques } \\
{ }^{\mathrm{E}} \mathrm{T}_{\mathrm{i}}{ }^{\mathrm{P}}: \text { External automated trading } \\
\\
\quad \text { Platforms }\end{array}$ \\
\hline $\begin{array}{l}\text { Clearing and settlement } \\
\text { \{Back office }\}\end{array}$ & I/R : Inventory & $\begin{aligned} \text { CDS : } & \text { Canadian Depository for } \\
& \text { Securities } \\
{ }^{\mathrm{s}_{\mathrm{K}}:} & \text { Sell-side custodian } \\
\mathrm{PC}: & \text { Private clearing firm }\end{aligned}$ \\
\hline Middle office & \multicolumn{2}{|l|}{$\begin{array}{l}\text { Risk management and trade policy } \\
\text { Credit compliance } \\
\text { Regulations }\end{array}$} \\
\hline
\end{tabular}


Table 2: Legend for Figure 3

\begin{tabular}{|c|c|c|}
\hline Description & Internal & External \\
\hline Buy-Side Management & $\begin{array}{l}\mathrm{M}_{\mathrm{FI}}^{\mathrm{S}}: \text { Senior FI Portfolio Manager } \\
\mathrm{MP}_{\mathrm{i}} \text { : Portfolio Managers/Traders } \\
\mathrm{A}_{\mathrm{i}}^{\mathrm{Q}}: \text { Quantitative Analysts } \\
\mathrm{A}_{\mathrm{i}}: \text { Analysts/Associate/Assistants } \\
\quad \text { /Trainees }\end{array}$ & $\begin{array}{l}\mathrm{S}_{\mathrm{i}}: \text { Sell-Side Fixed Income Sales Reps that } \\
\text { includes the retail sales force (Sales/Traders) } \\
\mathrm{T}_{\mathrm{i}}: \text { Sell-Side Market Makers or Traders } \\
\text { ATS }_{\mathrm{i}}: \text { Alternative Trading System }\end{array}$ \\
\hline Market's Public Information & & $\begin{array}{l}{ }^{\mathrm{P}} \mathrm{I}_{\mathrm{i}}: \text { Public Info from vendors } \\
{ }^{\mathrm{E}} \mathrm{T}_{\mathrm{i}}^{\mathrm{P}}: \text { External Trading Platforms } \\
{ }^{\mathrm{E}} \mathrm{R}_{i}: \text { External Research }\end{array}$ \\
\hline $\begin{array}{l}\text { Clearing and Settlement } \\
\{\text { Back office }\}\end{array}$ & $\begin{array}{l}\text { PMS: Portfolio Management Sys. } \\
\text { PAS: Portfolio Accounting Sys. }\end{array}$ & $\begin{aligned} \text { CDS : } & \text { Canadian Depository for } \\
& \text { Securities } \\
{ }^{\mathrm{B}} \mathrm{K}: & \text { Buy-side Custodian } \\
\mathrm{PC}: & \text { Private Clearing fïrm }\end{aligned}$ \\
\hline $\begin{array}{ll}\text { Managers' } & \text { Private } \\
\text { Information } & \end{array}$ & $\begin{array}{l}{ }^{\mathrm{I}} \mathrm{R}: \text { Internal Research } \\
{ }^{\mathrm{I}} \mathrm{C}_{\mathrm{i}}: \text { Internal Contacts } \\
{ }^{\mathrm{G}} \mathrm{I}_{\mathrm{i}}: \text { Pricing platforms }\end{array}$ & ${ }^{\mathrm{E}} \mathrm{C}_{\mathrm{i}}$ : External Contacts \\
\hline Middle office & $\begin{array}{l}\text { Risk Management and Trade Policy } \\
\text { Credit Compliance } \\
\text { Regulations }\end{array}$ & \\
\hline
\end{tabular}


.

$$
\begin{gathered}
\text { Innis Ref. } \\
\text { HF } \\
5548.32 \\
\text { M } 38.5 \\
n 0.20
\end{gathered}
$$




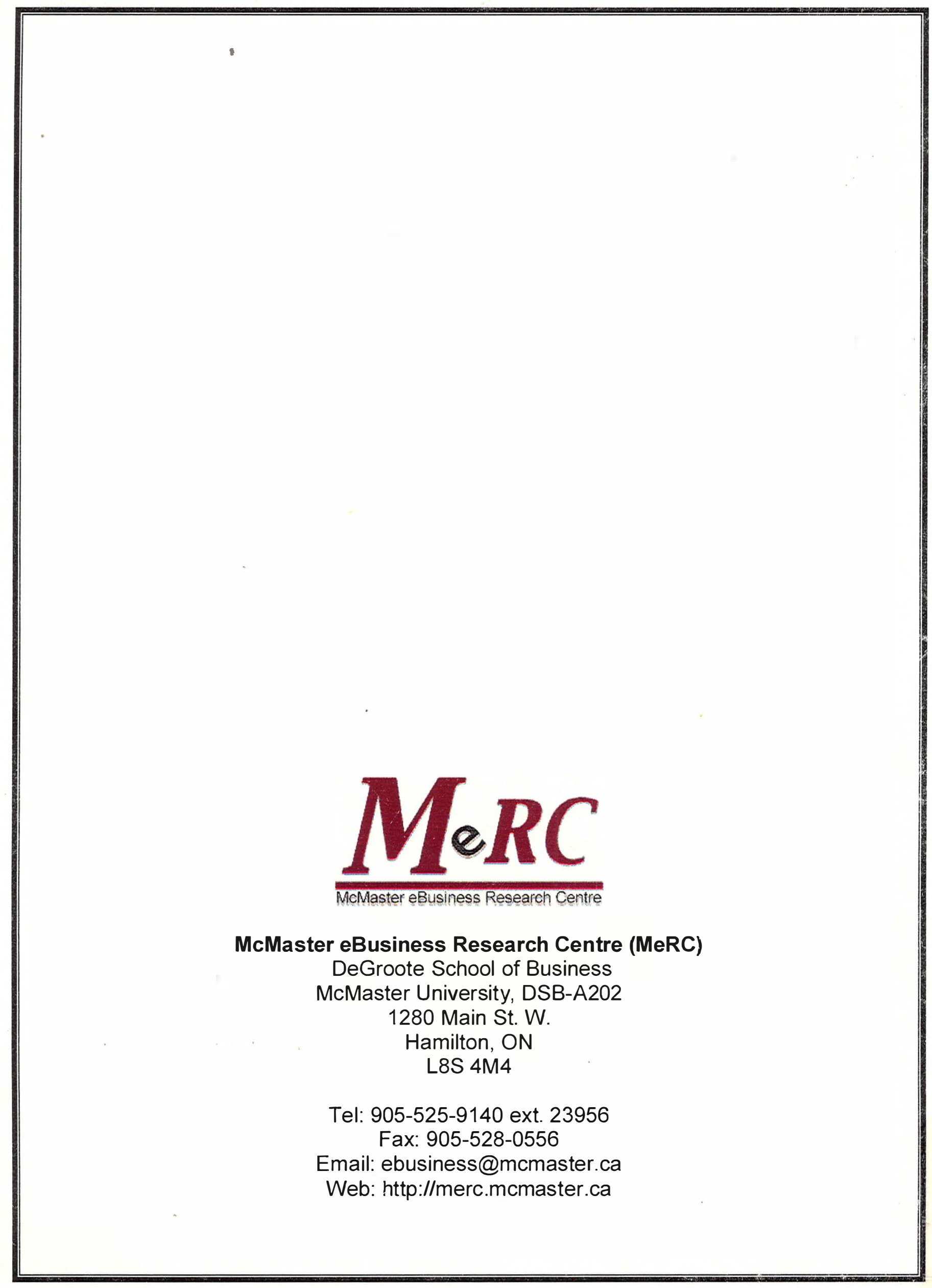

